\title{
Herbaceous periwinkle, Vinca herbacea Waldst. et Kit. 1799 (Apocynaceae), a new species of the Croatian flora
}

\author{
JÁNOS CSIKY ${ }^{1}$, Dragica PURGER ${ }^{2 *}$ \\ ${ }^{1}$ Department of Plant Taxonomy and Geobotany, Institute of Biology, \\ Faculty of Sciences, University of Pécs, Hungary \\ ${ }^{2}$ National Institute for the Environment H-7623 Pécs, Köztársaság tér 7, Hungary
}

\begin{abstract}
Populations of herbaceous periwinkle, Vinca herbacea Waldst. et Kit., were found on April 2007 on Bansko Hill (Baranja, Croatia), which lies on the south-western edge of the range of this Pontic-Pannonian species. Since $V$. herbacea was included neither in the handbooks for plant identification nor in the current Croatian Flora Database, a new key for the determination of Vinca L. species of Croatia is presented herein. The herbaceous periwinkle should be treated as a critically endangered (CR) species in Croatia, considering the low number of individuals and the small extent of its occurrence in extremely rare habitats at the margin of its distribution. New recordings of some very rare or »data deficient « (DD) taxa of Croatia are also presented here: Scorzonera hispanica L. and Inula germanica $\mathrm{L}$.
\end{abstract}

Key words: Bansko Hill, Continental, Loess, Pannonic, Steppe.

\section{Introduction}

The herbaceous periwinkle Vinca herbacea Waldst. et Kit. 1799 (Apocynaceae) (syn. Vinca mixta Velen., Vinca pumila E.D.Clarke) is a plant native to South-Western Asia from the Caucasus Mountains around the Black Sea through Anatolia and the Balkan Peninsula to the eastern part of the Danube valley and the Carpathian Basin, but its area is disjunctive (Meusel et al. 1978). It is distributed in southern and central Europe: the southern-central part of former SSSR: Russian Federation and Ukraine (PoBEDIMOVA 1952), Bulgaria (Delipavlov 1983), Serbia (Obradović et al. 1986), Hungary (Soó 1966, KirÁly 2009), Austria (FISCHER et al. 2008), Slovakia (RANDUŠKA and KRIŽO 1986), Romania, Greece and Turkey (STEARN 1972). Vinca herbacea is a lowland-colline, Pontic-Pannonian flora element (JÁvorKa 1925, Soó 1966, MeusEl et al. 1978). The occurrence of this species was indicated for the eastern part of Croatia in JÁvORKA (1925), but this record was never given

\footnotetext{
* Corresponding author, e-mail: dragica.purger@neki.gov.hu

Copyright $^{\circledR} 2013$ by Acta Botanica Croatica, the Faculty of Science, University of Zagreb. All rights reserved.
} 
any precise location. It cannot be found in the handbooks for determination of plants in Croatia (DomAC 1984, 2002), it is absent from the Red Book of Vascular Flora (NiKOLIĆ and TOPIĆ 2005) as well as from the current national database of the Croatian flora (NIKOLIĆ 1997, 2012). There are no data about this plant in the papers dealing with the flora of Bansko Hill (Godicl 1980, Sturc 1988, PuRger and Csiky 2008) or Baranja (PAnjKović 1990, ZAHIROVIĆ 2000). Therefore Vinca herbacea should be treated as a new taxon and included in the current Croatian Flora Database.

Vinca herbacea is a herbaceous perennial vascular plant with procumbent or ascending stems, and a length up to $60(-80 \mathrm{~cm})$, dying back at the end of autumn. Leaves are narrowly lanceolate or narrowly elliptical, the lowermost sometimes obovate, cuneate at base, with margins minutely ciliate. Pedicels are shorter than the subtending leaves (STEARN 1972). Flowers are well spaced along the stems. Calyx-lobes are 4-8 $\mathrm{mm}$, very narrowly triangular, with the margins smooth, ciliate or scabrid. Corolla is deep blue in colour. Corolla-tube is $10-15 \mathrm{~mm}$, limb is $20-35 \mathrm{~mm}$ in diameter, blue, lobes are acute or very obliquely truncate. The flowers are produced in spring (April - May) (WALDSTEIN and KITAIBEL 1802, KIRÁLY 2009).

There are two other native periwinkle species occurring in Croatia: the bigleaf periwinkle Vinca major and the common periwinkle V. minor (DOMAC 1984). The latter species is similar in the vegetative stage to the herbaceous periwinkle and therefore our aim was to make a new key for determination of the Vinca L. species of Croatia based on the descriptions of WALDSTEIn and KitAibel (1802), StEARn (1972), BÉNYEi-HimMER et al. (1999) and KIRÁLY (2009). In this paper we also present new records from the same steppe habitats of some very rare or »data deficient « (DD) taxa of Croatia.

\section{Material and methods}

\section{Study area}

Bansko Hill (Bansko brdo) is an elevation consisting of loess sediments (243 m a.s.1.), $21 \mathrm{~km}$ long, stretching in a NE-SW direction in NE Croatia (BoGNAR 1990). Its south-eastern part is a sheer, 25-58 $\mathrm{m}$ high loess cliff, facing onto the floodplain of the Danube. In consequence of the steep slope the precipitation cannot wet the soil sufficiently. The loess cliffs, exposed to sunshine (irradiation) and drying by winds, are extremely hot and dry in the summer time, cold and dry in the winter, so they function as extrazonal semi-deserts and orographic deserts in the zone of the closed oak forests and forest steppes (Pócs 1999).

The climate of NE Croatia is moderately continental: the mean annual temperature is $10-11^{\circ} \mathrm{C}$, precipitation is $600-700 \mathrm{~mm}$ with two maxima (late spring and beginning of autumn) that show the sub-Mediterranean feature of this climate (SELETKOVIĆ and KATUŠIN 1992).

\section{Plant identification and mapping}

Plant identification was done by using recent Hungarian (KIRÁLY 2009) and Croatian (DomAC 1984, 2002) handbooks. In line with the Central European Flora Mapping System (NIKOLIĆ et al. 1998) we compiled the distribution map of Vinca herbacea in Croatia. Examples of plants were collected on Bansko Hill and deposited in the Zagreb Herbarium (ZA). Geocoding of the site was performed with the use of a GPS device. 
For classification of $V$. herbacea into IUCN red list categories we used criteria from NikOLIĆ (2005).

\section{Results and discussion}

As a result of a survey of the loess flora and vegetation of Bansko Hill (NE Croatia) from Zmajevac to Batina four populations of herbaceous periwinkle were recorded in the 0178/4 Central European Flora mapping grid (Figs. 1-3).

WGS 84 coordinates, altitude, population size and brief habitat descriptions:

1. Lat. 45.854603, lon. 18.843011, $127 \mathrm{~m}$ a.s.l., small patches, in a secondary xero-mesophilous wood,

2. Lat. 45.837268 , lon. $18.840533,113 \mathrm{~m}$ a.s.l., small patches, in a semi-natural steppe-forest complex,

3. Lat. 45.833397 , lon. $18.839234,103 \mathrm{~m}$ a.s.l., small patches, in a semi-natural forest-steppe wood,

4. Lat. 45.827463 , lon. $18.833783,105 \mathrm{~m}$ a.s.l., large patches, on a steep loess wall with secondary scrub and grassland vegetation.

\section{Key for determination of Vinca species}

1.a Stems rooting on peaks, dying back in the end of autumn. Upper leaves narrowly lanceolate or narrowly elliptical, cuneate at base, $(2-) 3(-5) \mathrm{cm}$ long, $0.5-1.5 \mathrm{~cm}$ wide, almost sessile. Margins of calyx-lobes smooth, ciliate or scabrid. Fruit apex acute, almost rostrate. V. herbacea Waldst. et Kit.

1.b Stems are over-wintering, rooting on nodes. Petiole $1-9 \mathrm{~mm}$ long $\ldots \ldots \ldots \ldots \ldots \ldots .2$

2.a Upper leaves are lanceolate or elliptical, (2-)4(-5) cm long, 1-2.5 cm in width, petiole 1-4 mm long. Margins of calyx lobes are smooth. Fruit apex blunt....... V. minor L.

2.b Upper leaves are ovate, near the base cordial-ovate, $4-8 \mathrm{~cm}$ long, $2-6 \mathrm{~cm}$ in width, petiole 5-9 mm long. Margins of calyx lobes are ciliate. Fruit apex acute....... V. major L.

\section{Ecology of Vinca herbacea}

Vinca herbacea is a xero-mezophytic species, populations of which were found on steep south-facing slopes as well as on plateau of Bansko Hill. This species mostly grows in steppe habitats, in dry rocky places, on shallow soils, humic or sandy soils in dry- and in xero-mesophilous steppe grasslands, forest steppes as well as in shrubberies and oak forests (SoÓ 1966, RANDUŠKA and KRIŽO 1986). This is a plant with narrow ecological stress tolerance (BORHIDI 1995). The herbaceous periwinkle is an entomophilous species, while its propagules are spread by anemochory, and it flowers from April to the beginning of June (Soó 1966). Most of the individuals were flowering in April in 2007 in Bansko Hill, much earlier than the average in Hungary. Some of the individuals were infected by yellow fungus on the back of the leaves, but this fungus does not kill its host. 


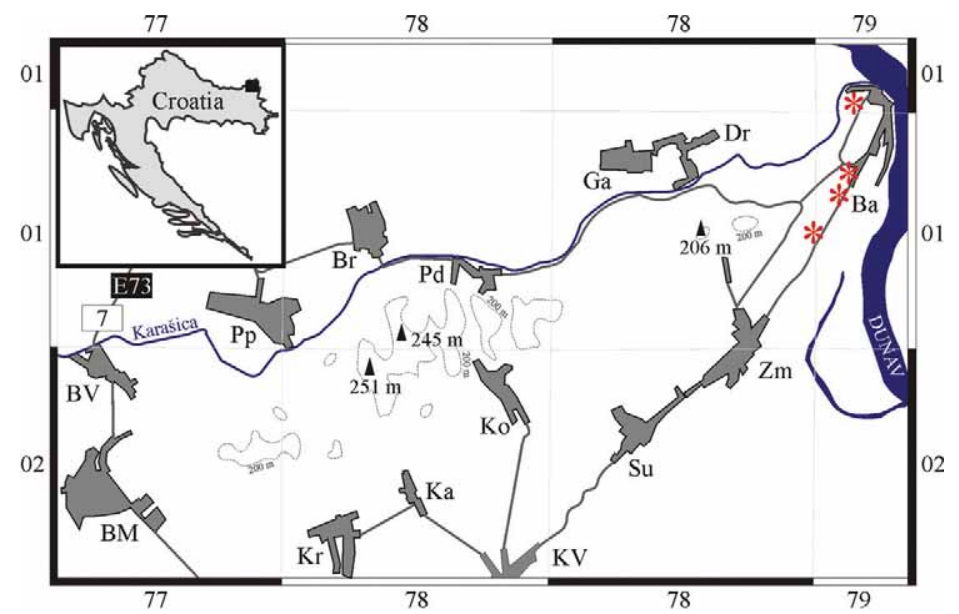

Fig. 1. Distribution of Vinca herbacea $(*)$ in Bansko Hill (Croatia). Abbreviations: Ba-Batina; BM Beli Manastir; Br - Branjina; BV - Branjinski Vrh; Dr - Draž; Ga - Gajić; Ka - Kamenac; Kr - Karanac; Ko - Kotlina; KV - Kneževi Vinogradi; Pd - Podolje; Pp - Popovac; Su Suza; Zm - Zmajevac (drawn by János Csiky and Toni Nikolić)
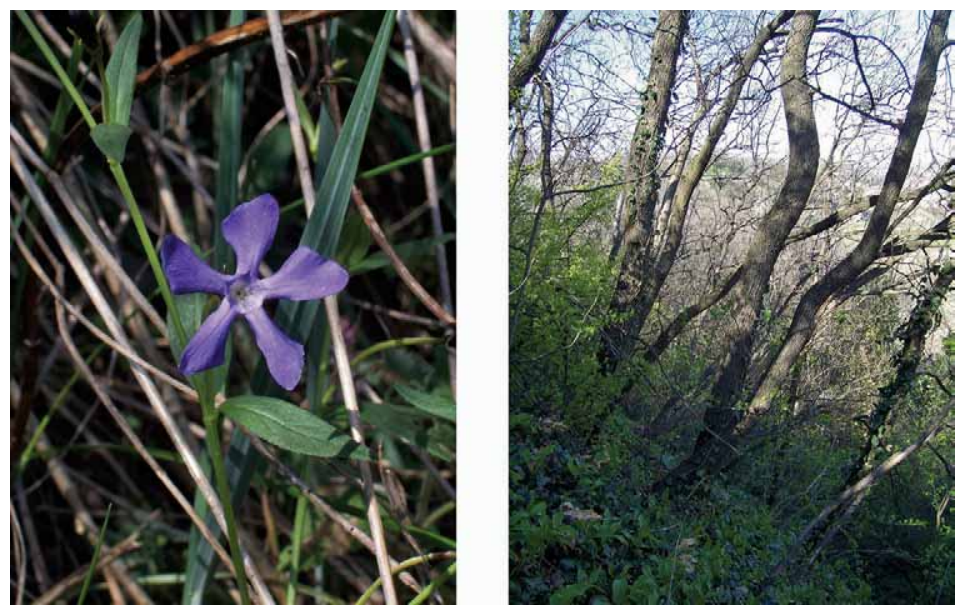

Fig. 2. and 3. Flowering Vinca herbacea and its habitat on Bansko Hill, near Zmajevac (Photo by János Csiky)

\section{Distribution in the neighbouring area and conservation status}

Closest to the Croatian locality, Vinca herbacea was found in southern Hungary Baranya County (Soó 1966) on the Villány Hills and Mecsek Mountains (FARKAS 1999). In Serbia it occurs in Fruška Mountains, in the Deliblato sand area, in the vicinity of Belgrade (Višnjička kosa, Košutnjak) and near Kragujevac (Resnik) (STJEPANOVIć-VesELIČIć 1973). It was also found in a sandy area near Subotica, Vršačke Mountains and Titel Hill (OBRADOvić et al. 1986). The herbaceous periwinkle is a relict from the Boreal, having persisted in steppe habitats (OBRADOvić et al. 1986). 
In the Carpathian Basin Vinca herbacea is a scarce and in Hungary a protected species (FARKAS 1999) but not endangered (NÉMETH 1989, KIRÁLY 2007), rare in Austria (FISCHER et al. 2008), endangered in Slovakia (FERÁKOVÁ et al. 2001) and common in Romania (OPREA 2005). In Serbia it is protected, but not threatened (STEVANOviĆ 1999). Threatening factors in the whole area of distribution are the small populations, the low number of flowering individuals, intensive pasturing, burning of grasslands in spring, clearings of shrubs and trees (Pobedimova 1952).

The habitat type of Vinca herbacea is extremely restricted in Croatia; the extent of its occurrence is less than $10 \mathrm{~km}^{2}$. There are fewer than 1000 adult individuals in the population. Based on these two criteria (NIKOLIĆ 2005) Vinca herbacea should be treated as a critically endangered (CR) species of the Croatian flora. A survey of the populations performed in 2010 shows that the populations had not been significantly changed in the previous three years; nevertheless, a continued monitoring is needed (CSIKY and PURGER 2008).

\section{Occurrence of some rare plants in the same area}

In the same steppe habitats on Bansko Hill (lat. 45.837268, lon. 18.840533, $113 \mathrm{~m}$ a.s.l., in a semi-natural steppe-forest complex) we found some heliophilous and xerotolerant species which are »data deficient « vascular plant taxa of Croatia (NIKOLIć 2012):

Scorzonera hispanica L. is extremely rare, found in only a few localities in Mediterranean regions of Croatia. It is distributed in the eastern part of the Illyrian province (JÁVORKA 1925). In Serbia it was found in the vicinity of Novi Sad (ZORKÓCZY 1896) but this information was not confirmed later (OBRADOvić and ButORAC 1975). In Hungary this species occurs in the southern part of the country, in the Mecsek Mountains (Soó 1970).

Inula germanica L. is a very rare plant in Croatia. This species was found closest to the Croatian locality in Hungary, in the Mecsek Mountains and very rarely occurs in Baranya-, in the Geresdi- and Szekszárdi-Hills (FARKAS 1999, PURGER 2002).

These are rare sub/Mediterranean, and sub-continental species that occur on the southern loess slopes of Bansko Hill as well as other extremely rare continental species in Croatia (CSIKY et al. 2008, Purger et al. 2008).

\section{Acknowledgement}

We thank Julia Török for proofreading the English version of the article. This survey was carried out with permission given by Ministry of Culture of Republic Croatia. It was supported by INTERREG III A, SLO-HU-CRO 2006/01/167/HU Project.

\section{References}

BÉNYei-Himmer, M., FACsar, G., Udvardy, L., 1999: Data on the reproductive biology of the native Vinca species (in Hungarian). Kitaibelia 4, 165-167.

BognAR, A., 1990: Geomorphology of Baranja (in Croatian). Savez geografskih društava Hrvatske, Zagreb.

BoRHIDI, A., 1995: Social behaviour types, the naturalness and relative ecological indicator values of the higher plants in the Hungarian flora. Acta Botanica Hungarica 39, 97-181. 
Csiky, J., Purger, D., 2008: Monitoring of plant species along the Drava river and the Hungarian-Croatian border. In: PURGER J. J. (ed.), Biodiversity studies along the Drava river, 13-56. University of Pécs, Pécs.

Csiky, J., Purger, D., Nikolić, T., 2008: Reseda inodora Rchb., a new species of the Croatian flora. Acta Botanica Croatica 67, 229-235.

DeliPAVlov, D., (ed.), 1983: Book for determination of plants in Bulgaria (in Bulgarian). Zemizdat, Sofia.

DomAC, R., 1984: Flora of Croatia and neighbour regions (In Croatian). Školska knjiga, Zagreb.

DOMAC, R., 2002: Flora of Croatia (In Croatian). Školska knjiga, Zagreb.

FARKAS, S., (ed.), 1999: Protected plants of Hungary (in Hungarian). Mezogazda Kiadó, Budapest, 182-83 pp.

FERÁKOVÁ, V., MAGLOCKÝ, Š., MARHOLD, K., 2001: Red list of ferns and flowering plants of Slovakia (December 2001) (in Slovakian). In: Baláž, D., Marhold, K., Urban, P. (eds.), Red list of plants and animals of Slovakia, Nature Conservation. Ochrana Prírody 20 (Suppl.), 48-81.

FISCHER, M. A., OswALD, K., AdLER, W., 2008: Excursionsflora von Österreich, Liechtenstein, Südtirol. 3. Auflage, Biologiecentrum der Oberösterreichischen Landesmuseen, Linz.

GodicL, L., 1980: Steppenflora in Nordwest-Jugoslawien. (in Slovenian). Slovenska Akademija Znanosti in Umetnosti, Razprave 1, V Razreda SAZU 22, 279-367.

JÁvORKA, S., 1925: Flora of Hungary (in Hungarian). Studium, Budapest.

KIRÁly, G., (ed.), 2007: Red list of the vascular flora of Hungary (in Hungarian). Private Edition, Sopron, $72 \mathrm{pp}$.

KIRÁLY, G., (ed.), 2009: New Hungarian Herbal. The Vascular Plants of Hungary. Identification key (in Hungarian). Aggtelek National Park Directorate, Jósvafo. 616 pp.

Meusel, H., JäGer, E., Rauschert, S., Weinert, E., 1978: Vergleichende Chorologie der zentraleuropäischen Flora 2. VEB Gustav Fischer Verlag, Jena.

NÉMETH, F., 1989: Vascular plants (in Hungarian). In: RAKOnCZAY, Z. (ed.), Red Book. Extinct and endangered animals and plants in Hungary, 265-325. Akadémiai Kiadó, Budapest.

Nikolić, T., 1997: Flora Croatica. Index Florae Croaticae, 2. Natura Croatica 6, 5-232.

Nikolić, T., 2005: Assessment of threats (In Croatian). In: Nikolić, T., Topić, J. (eds.), Red Book of Vascular Flora of Croatia, 24-34. Ministry of Culture, State Institute for Nature Protection. Zagreb.

Nikolić, T., (ed.) 2012: Flora Croatica Database, Department of Botany and Botanical Garden, Faculty of Science, University of Zagreb. Retrieved December 29, 2012 from http://hirc.botanic.hr/fcd

Nikolić, T., Bukovec, D., Šopf, J., JelaskA, S. D., 1998: Flora mapping of Croatia: Possibilities and standards (in Croatian). Natura Croatica 7 Suppl. 1, 1-62.

Nikolić, T., Topić, J., (eds.), 2005: Red book of vascular flora of Croatia (in Croatian). Ministry of Culture, State Institute for Nature Protection. Zagreb. 
OBradović, M., Butorac, B., 1975: Einige Phlanzengeographishe Charakteristiken der Flora der Umgebung von Petrovaradin. (in Serbian with German summary). University of Novi Sad, Review of research Faculty of Science, Biology series 5, 179-204.

Obradović, M., Stanojev-Igić, R., Panjković-Matanović, V., 1986: Boreal relicts in the flora of Voivodina Province (in Serbian). Proceeding of Natural Science Matica Srpska, Novi Sad 71, 41-54.

OpreA, A., 2005: Critical list of vascular plants in Romania (in Romanian). University of Alexandru Ioan Cuza, Iasi.

PANJKović, B., 1990: Life form and floral elements in the flora of Baranja (Croatia) (in Croatian). Acta Botanica Croatica 49, 107-123.

Pobedimova, E. G., 1952: Vinca L. In: Komarow, V. L. (ed.), Flora SSSR, 18 (in Russian). Akademia Nauk SSSR, Moskva-Leningrad.

Pócs, T., 1999: Studies on the cryptogamic vegetation of loess cliffs, 1. Orographic desert in the Carpathian Basin (in Hungarian and English). Kitaibelia 4, 143-156.

Purger, D., 2002: Data on flora of Baranya-, Geresdi- and Szekszárdi-Hills regions (in Hungarian). In: SAlAmon Albert É. (ed.), Hungarian botanical surveys on the beginning of Millennium - studies in honour of Borhidi Attila 70 anniversary, 283-296. PTE Növénytani Tanszék, Pécs.

Purger, D., Csiky, J., 2008: Plants of Bansko Hill (Baranja, Croatia) (in Croatian). University of Pécs, Pécs.

Purger, D., Csiky, J., ToPić, J. 2008: Dwarf iris, Iris pumila L. (Iridaceae) - new species of the flora of Croatia. Acta Botanica Croatica 67, 97-102.

RANDUŠKA, D., KRIŽO, M., 1986: Protected plants. (in Slovakian). Priroda, Bratislava.

Seletković, Z., KATuŠIn, Z., 1992: Climate of Croatia. In: Rauš, Đ. (ed.), Forests in Croatia (in Croatian), 13-18. Faculty of Forestry, University of Zagreb, Hrvatske šume p. o., Zagreb.

Soó, R., 1966: Manual for taxonomy and phytogeography, flora and vegetation of Hungary, 2 (in Hungarian). Akadémiai Kiadó, Budapest.

Soó, R., 1970: Manual for taxonomy and phytogeography, flora and vegetation of Hungary, 4 (in Hungarian). Akadémiai Kiadó, Budapest.

Stearn, W. T., 1972: Vinca L. In: Tutin, T. G. (ed.), Flora Europaea 3, 69. University Press, Cambridge.

STEVAnOvić, V. (ed.), 1999: The red data book of flora of Serbia 1. Extinct and critically endangered taxa (in Serbian). Ministry of Environment of the Republic of Serbia, Faculty of Biology, University of Belgrade, Institution for Protection of Nature of the Republic of Serbia, Belgrade.

StJePanović-Veseličić, L., 1973: Fam. Apocynacae Juss. In: Josifović, M. (ed.), Flora of Serbia (in Serbian), 394-400. Serbian Academy of Sciences, Belgrade.

STURC, B., 1988: Floristic and geobotanical data from loess hills in Baranya (in Hungarian). Pécsi Muszaki Szemle 33, 19-24.

Waldstein, F. A., KitAibel, P., 1802: Descriptiones et Icones Plantarum Rariorum Hungariae 1. Schmidt, Viennae. 
CSIKY J., PURGER D.

ZAHIROVIĆ, Ž. 2000: Rare and endangered plants of north-eastern part of Croatia (in Croatian). MSc Thesis. University of Zagreb, Zagreb.

ZoRKócZY, L., 1896. Flora of Novi Sad and surroundings (in Hungarian). Popovits. M. Testvérek Könyvnyomdája, Ujvidék. 